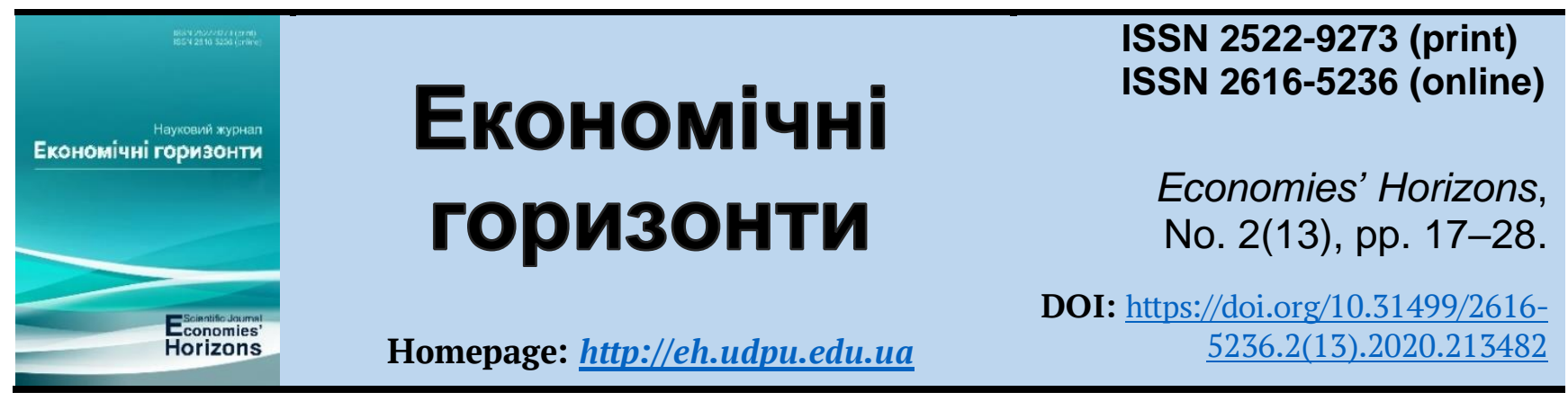

UDC 330:341.2:351.824.14

\title{
Modeling the relationship between utilities and partners
}

Received: 29 April 2020 Accepted: 30 May 2020

\author{
Oleksiy O. Topchiy ${ }^{1}$, Cand. Ec. Sc.
}

Topchiy, O. O. (2020), "Modeling the relationship between utilities and partners", Economies' Horizons, no. 2(13), pp. 17-28, doi: https://doi.org/10.31499/26165236.2(13).2020.213482

\begin{abstract}
The purpose of the article is to study the features of modelling the relationship between utilities and partners. Methodology. General scientific methods are used in the research, in particular, generalizations, comparisons - to analyse the views of scientists on modelling the relationship between utilities and partners, indicating the main forms of public-private partnership, the advantages and disadvantages of their use. Results. It is proved that the relationship between the state and business today is extremely strategically important for the state in the formation of sustainable development goals. Building effective relationships in housing and communal services will be a success for effective activities and will satisfy all participants: the state, business and the population. It is proved that in modern conditions, housing and communal services is a complex hierarchical system that combines many separate subsystems and has the characteristics of a spatial economy, i.e. regional structure and scale. The analysis of the legal and regulatory framework shows that there are only three players in the market of housing and communal services: managers, service providers and consumers. Also, there are various opportunities to establish partnerships with most existing stakeholders, including the use of publicprivate partnerships in housing and communal services. It is investigated that among the widespread variants of private capital raising in the communal sphere the following basic forms are identified: contract for works, contract for enterprise management, lease, concession, privatization. Thus, local public authorities have the opportunity to transfer utilities in concession or lease to private investors. However, this has not become a common practice due to the complexity of their organizational mechanism. Practical meaning. It is proved that the most effective form of public-private partnership for housing and communal services is a concession - the process of granting, in order to meet public needs by an authorized executive body or local government, concluding a contract on a paid and fixed basis, the concessionaire ) management of the concession object, on the terms of property liability by the concessionaire and possible division of business risk. Prospects for further research. The need to study the advantages and disadvantages of other forms of public-private partnership in housing and communal services.
\end{abstract}

Keywords: housing and communal services, urban agglomerations, public-private partnership, privatization, rent, leasing, concession, relationship modelling.

${ }^{1}$ Public Institution "Institute of Environmental Economics and Sustainable Development of the National Academy of Sciences of Ukraine"; Doctoral Student; ORCID ID: https://orcid.org/0000-0001-6414-0561; e-mail: management@nuos.edu.ua. 
JEL Classification: C00, L97, L98, L99.

Number of references: 16; number of tables: 1; number of figures: $\mathbf{3}$; number of formulas: $\mathbf{0 .}$

\section{Моделювання взаємовідносин між комунальними структурами та партнерами}

\section{Олексій Олександрович Топчій ${ }^{1}$}

Стаття надійшла: 29.04.2020 Стаття прийнята: 30.05.2020
Topchiy O. O. Modeling the relationship between utilities and partners. Економічні горизонти. 2020. № 2(13). C. 17-28. DOI: $10.31499 / 2616-$ 5236.2(13).2020.213482

Анотація. Метою статті $\epsilon$ дослідження особливостей моделювання взаємовідносин між комунальними структурами та партнерами. Методологія. У досліджені застосовані загальнонаукові методи, зокрема узагальнення, порівняння - для аналізу поглядів науковців щодо моделювання взаємовідносин між комунальними структурами та партнерами, зазначення основних форм державно-приватного партнерства, переваг і недоліків їх використання. Результати. Доведено, що взаємовідносини держави і бізнесу, сьогодні $є$ надзвичайно стратегічно важливими для держави при формуванні цілей сталого розвитку. Побудова результативних взаємовідносин у житлово-комунальному господарстві стане успіхом ефективної діяльності і задовольнить всіх учасників: державу, бізнес і населення. Доведено, що в сучасних умовах житлово-комунального господарства являє собою складну ієрархічну систему, що об’єднує чимало окремих підсистем і має ознаки просторової економіки, тобто регіональну структурованість і масштабність. Аналіз законодавчо-нормативної бази показав, що на ринку житлово-комунальних послуг функціонують всього три гравців: управителі, виконавці послуг і споживачі. Також, існують різні можливості налагодження партнерських взаємовідносин із більшістю наявних стейкхолдерів, зокрема використання державно-приватного партнерства у ЖКГ. Досліджено, що серед розповсюджених варіантів залучення приватного капіталу до комунальної сфери виділяють такі основні форми: договір на виконання робіт, контракт на управління підприємством, оренда, концесія, приватизація. Так, місцеві органі публічної влади отримали можливість передати комунальні підприємства в концесію або оренду приватним інвесторам. Однак це не стало поширеною практикою з причини складності їх організаційного механізму. Практичне значення. Доведено, що найбільш ефективною формою державно-приватного партнерства для житловокомунального господарства виступає концесія - процес надання, з метою задоволення публічних потреб уповноваженим органом виконавчої влади чи органом місцевого самоврядування, заключаючи договір на платній й строковій основі, концесіонеру права на створення та (або) управління об'єктом концесії, на умовах майнової відповідальності концесіонером й можливого розділення підприємницького ризику. Перспективи подальщих досліджень. Необхідність дослідження переваг й недоліків інших форм державно-приватного партнерства у житловокомунальному господарстві.

Ключові слова: житлово-комунальне господарство, міські агломерації, державно-приватне партнерство, приватизація, оренда, лізинг, концесія, моделювання взаємовідносин

Кількість джерел: 16; кількість таблиць: 1; кількість рисунків: 3; кількість формул: 0.

\footnotetext{
${ }^{1}$ ДУ «Інститут економіки природокористування та сталого розвитку НАН України»; докторант; ідентифікатор ORCID: http://orcid.org/0000-0001-6414-0561; e-mail: management@nuos.edu.ua.
} 


\section{Introduction.}

Effective management of the process of state and business interest's coordination takes into account innovative trends in economic development and the achievement of certain strategic and tactical goals for all participants in housing and communal services.

Today, successful management models and positive results of public-private partnership are explained by the interaction of state and business. They are characterized by the recognition of the urgency of stimulating intersectoral cooperation by government agencies representatives and entrepreneurs. However, it should be noted the lack of system in solving problems. There is a lack of a clear definition of mechanisms for managing the transformation of relations between the state and business in the context of stimulating the socio-economic housing and communal services development.

Changes and improvements in the legal framework lead to greater opportunities for cooperation between the state and business. Particular attention is paid to the study of such relationships in housing and communal services as a strategically and socially important component of the society.

\section{Literature review.}

Peculiarities of modeling the relationship between communal structures and partners were studied by domestic and foreign scientists, in particular: I. Panasenko (2013), M. Melnykova, O. Tarasevych and H. Nesterov (2015), M. Masyk (2015), V. Kucherenko V. R. and S. Dzezyka (2009), L. Chernyshov (1998), P. Bubenko, I. Pokutsa and V. Vashchenko (2013), O. Karelin (2010), O. Vikarchuk (2005), O. Zerova (2014), I. Sincheskul and O. Dymchenko (2018), I. Irtyshcheva I. O. and I. Kramarenko (2014).

However, constant changes in the legal framework, the construction of strategically important documents for the state require additional research to determine the features of modeling the relationship between utilities, partners, government and their consumers.

\section{Methodology.}

The theoretical and methodological basis of the study are scientific papers in the field of housing and communal services of urban agglomerations. To achieve the purpose of the article, the following research methods were used: theoretical generalization - to determine the theoretical foundations and trends in the content and components of modeling the relationship between utilities and partners; system approach - to generalize the forms of relationships between utilities and partners; methods of positive and normative analysis to develop recommendations for improving the modeling of the relationship between utilities and partners.

\section{Research objectives.}

The aim of the article is to study the features of modelling the relationship between utilities and partners.

\section{Results and discussions.}

We agree with the opinion of I. Panasenko that “...housing and communal services is the object of spatial economy (regional structure and scale), on the one hand, and on the other - of industry specifics (multifunctional complex - housing, transport, water supply, roads), which provides services to the population and territorial objects" (Panasenko, 2013). However, reforms and ongoing development processes are changing the requirements for a multifunctional housing and communal complex. Today, the sectoral specifics of housing and communal services include: landscaping, housing, economy and tariff policy, heat supply, water supply and drainage, energy efficiency and energy saving (Figure 1).

In modern conditions, housing and communal services is a complex hierarchical system that combines many separate subsystems:

a) housing policy (activities of condominiums, dormitories);

b) heat, water supply and drainage (heat power, water supply, drainage);

c) energy efficiency and energy saving (energy efficiency of buildings, equipping 
with commercial heat metering units);

d) landscaping (vehicle parking, green economy, road and bridge economy, outdoor lighting, stormwater maintenance, burial industry).

According to The Ministry of Communities and Territories Development of
Ukraine, housing and communal services regulate the tariff policy for sewerage, water supply, heat supply, maintenance of buildings and adjacent territories and control the state of payment for housing and communal services.

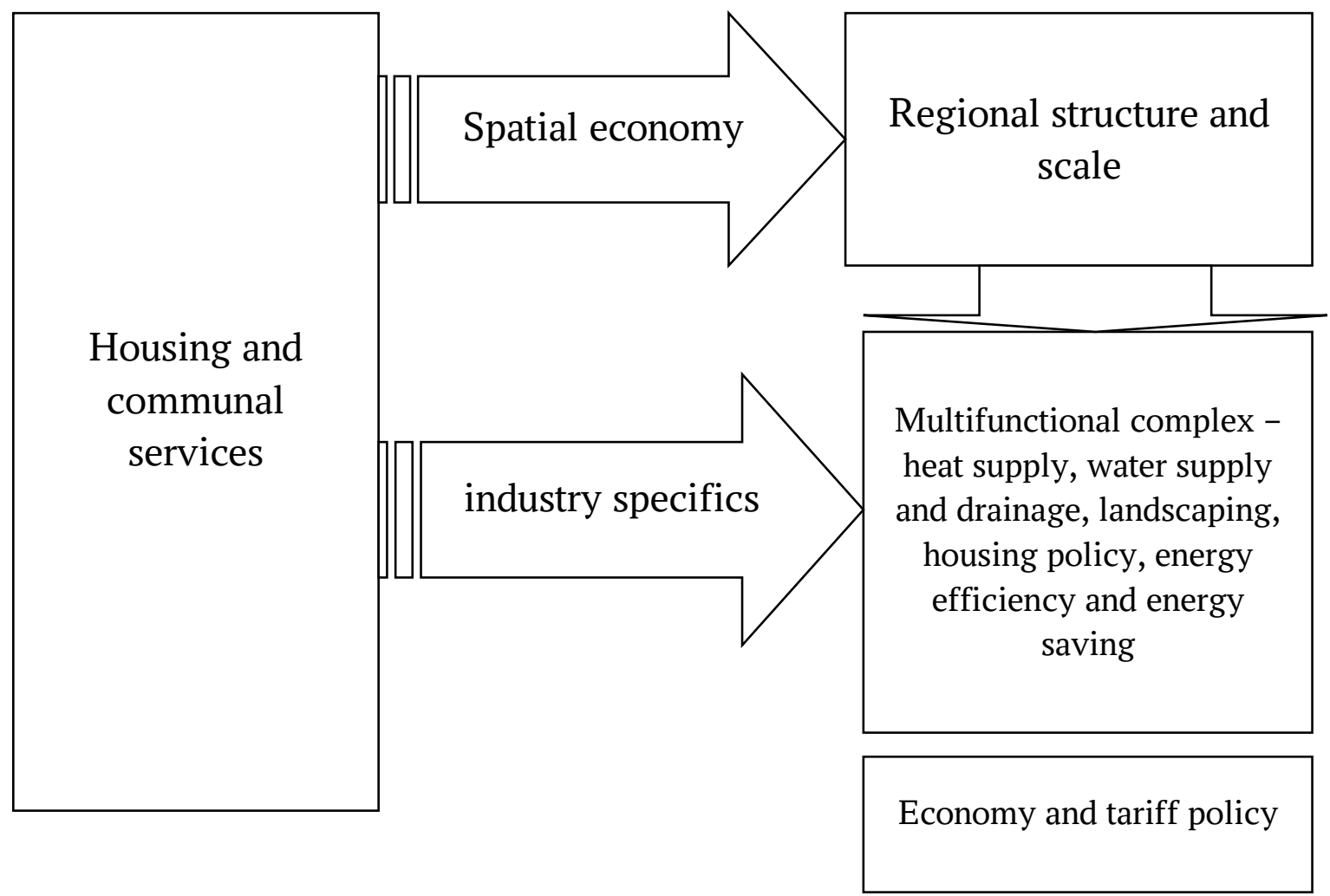

Fig. 1. Hierarchical system of housing and communal services in modern conditions

Source: compiled by the author based on (Panasenko, 2013).

In modeling the relationship, M. Melnykova, O. Tarasevych and $\mathrm{H}$. Nesterov took as a basis the process of a communal commercial enterprise functioning with economic agents. "Economic agents are communal commercial enterprises - production and economic complex (hereinafter "PEC"), its suppliers (hereinafter - "suppliers"), consumers of its products: population and business (hereinafter - "consumers"), the central and local authorities and administration (hereinafter - "state") - external interaction, as well as interaction within the enterprise: interaction of the head office with divisions and personnel interaction inside" (Melnykova, Tarasevych and Nesterov, 2015).

The main problem in the process of the utility functioning with economic agents is the lack of a single and common interaction between all elements of the described system. Suppliers do not interact with consumers of its products; both, of course, have their own relationship with the state, but these relationships are completely independent and not related to their interaction with service providers; contacts, conflicts and problems within utilities concern only its employees. The general interaction is divided into separate pairs, independent of each other, external interactions of the production and economic complex with suppliers, consumers, the state, as well as internal structural interactions: between the head office and departments, management and its production staff. 
However, today the main directions of the strategy of reforming the Ukrainian housing and communal services determine the relationship between the players of housing and communal services.

In 2018, the Law of Ukraine "On Housing and Communal Services" (The Verkhovna Rada of Ukraine, 2017) was adopted, accord- ing to which the market of housing and communal services defines three players: managers, service providers and consumers.

The relationship of managers, service providers and consumers in the market of housing and communal services are shown in Figure 2.

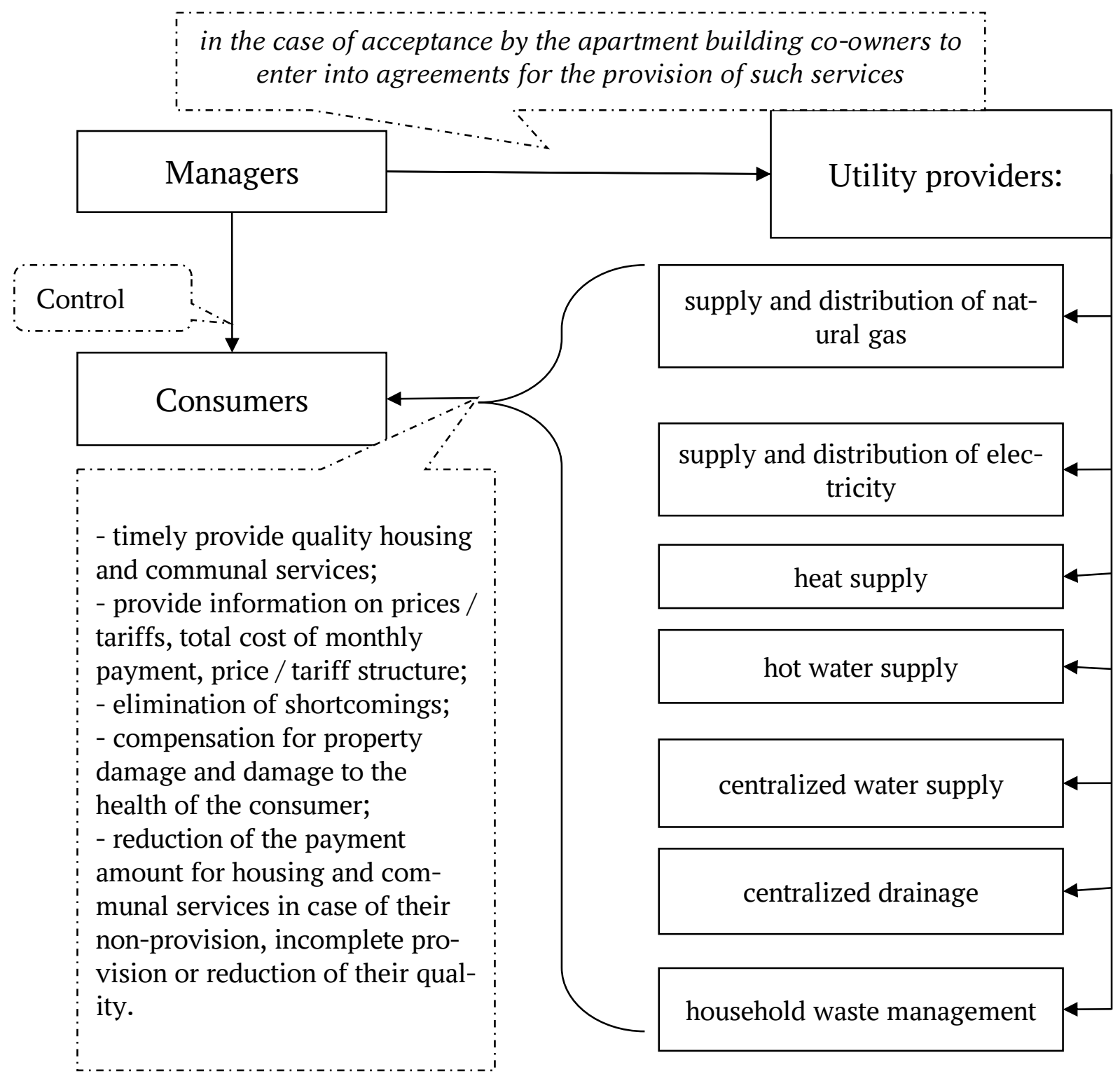

Fig. 2. The process of the relationship between utilities and consumers

Source: grouped by author.

Managers, in the case of acceptance by apartment building co-owners, may enter into contracts for the provision of such services with contractors. Utility providers provide, in accordance with current legislation, services to consumers in: supply and distribution of natural gas, supply and distribution of electricity, heat supply, hot water supply, central- ized water supply, centralized drainage, household waste management. The main obligations of utilities include:

- timely provide quality housing and communal services;

- provide information on prices / tariffs, total cost of monthly payment, price / tariff structure; 
- elimination of shortcomings;

- compensation for property damage and damage to the health of the consumer;

- reduction of the payment amount for housing and communal services in case of their non-provision, incomplete provision or reduction of their quality.

World practice shows that among enterprises the development of various forms of public services organization is becoming more and more important. The main ones are the establishment of private enterprises and the creation of state or communal enterprises.

Recently, the search for effective forms of partnership between the public and private sectors, according to which local authorities can manage independently (direct administrative management) or entrust the management of a private enterprise on the basis of certain conditions, is becoming more and more widespread (delegated management of utilities on the basis of management contracts, leases, concessions, etc.).

Direct administrative management is performed directly and exclusively by the local government, which has all the powers in the field of public utilities, independently finances investments (except for subsidies) and fully covers losses from the operation of the service. In this case, direct administrative management does not exclude the possibility of involving a private enterprise as a service or contracting firm.

Under current law, there are various opportunities to partner with most existing stakeholders. The development of publicprivate partnership in housing and communal services is gaining more and more attention among scientists. In Ukraine, opportunities to attract private investment in housing and communal services have expanded significantly. Thus, local councils have the opportunity to transfer utilities to concession or lease to private investors. However, this has not become a common practice due to the complexity of their organizational mechanism.
As a result, due to the over-regulation of this area, investors are in no hurry to invest in housing and communal services. The relationship between the participants of the public-private partnership in housing and communal services is obvious, both for the state and for the private partner, utilities and urban agglomerations, where the subjects of relations are located (Figure 3).

Among the main advantages of PPPs that arise between public and private partners is risk sharing, including: demand and market, regulatory, financial, macroeconomic, social, political risks, force majeure. Also, among the main benefits that a private partner receives are: obtaining guarantees and preferences for business development, the possibility of business development in the long run, the possibility of attracting debt financing. The state, on the other hand, receives longterm private investment and reduction of budget expenditures, the development of new management competencies. In turn, urban agglomerations are not left out: after receiving investments and infrastructure of PPP entities, the quality of service provision is expected to improve, which will increase the investment attractiveness of the territory and infrastructure management.

Among the common options for attracting private capital to the utilities sector are the following main forms: contract for works, contract for enterprise management, lease, concession, privatization.

According to Article 4 of the Law of Ukraine "On Privatization of State and $\mathrm{Mu}-$ nicipal Property" the objects of engineering infrastructure and improvement of cities, including networks, constructions, equipment, which are connected with the supply of water, gas, heat, as well as drainage and treatment of wastewater, are of national importance and can't be privatized (The Verkhovna Rada of Ukraine, 2018).

These circumstances indicate that the privatization of enterprises that belong to the sphere of natural monopolies in local utilities 
markets, allows to attract large amounts of capital investment in relatively short periods. But in the following stages, the work of private companies requires increasing regulatory influence from the state in order to restrain monopolistic manifestations of monopoly.
The main disadvantage is the almost complete impossibility of introducing competition between companies during their work, in contrast to other forms of private sector participation, which are more flexible (Kucherenko and Dzesyk, 2009).

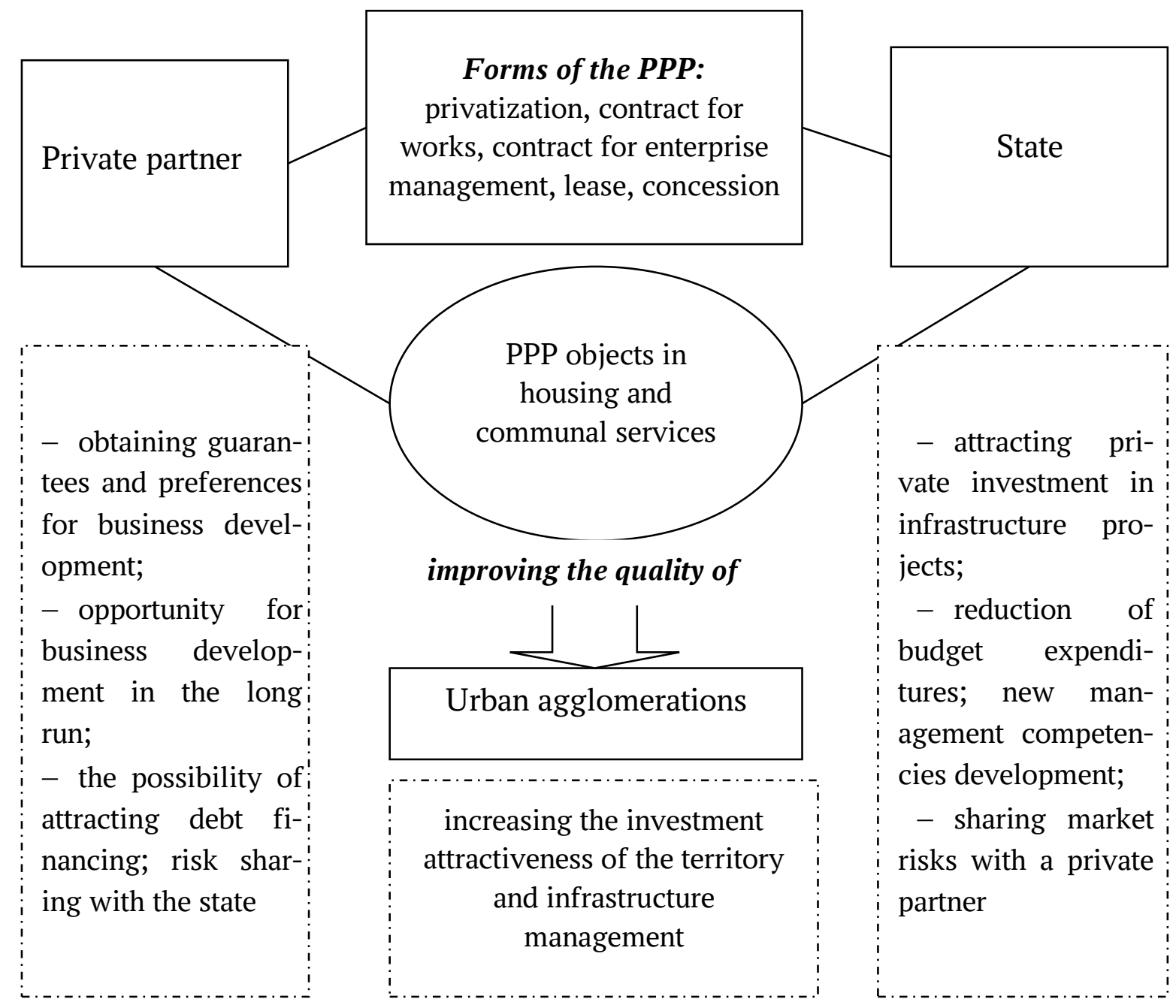

Fig. 3. Relationships between participants in the process of public-private partnership in housing and communal services

Source: improved by the author based on (Masyk, 2015)

In the housing and communal services, such a form of attracting a private investor as privatization will not soon be able to be applied. Many conditions and points must be taken into account, but the main prerequisite must be the formation of a sustainable socially oriented economy.

Thus, in order to attract private capital to the municipal sector of urban agglomerations, it is more appropriate to ensure the preservation of the functions of the owner, who, under pre-determined conditions, in- volves private entities in the provision of services. Such forms include contracts for works and management, concession, lease, partial privatization based on the acquisition of shares.

Contracts for the performance of certain works with other enterprises have the right at their discretion to enter into utility companies due to their status as commercial enterprises, in accordance with the Commercial Code of Ukraine. When concluding a contract for the provision of services, the utility delegates the 
performance of certain functions to a private company for a certain period of time. The overall responsibility for the provision of utilities remains with the state-owned enterprise, but in fact the work is performed by a private company.

The essence of trust management is to involve the state to manage their property of private operators. At the same time, an essential feature of trust management agreements is the existence of provisions on assigning to the state the rights to use, own and disposes of this property, while the other party receives only the right to exercise these powers on behalf of the owner. Upon expiration of the contract, the manager is obliged to return the property that was transferred to him in management. In order to prevent the covert privatization of such facilities, it is important to establish the terms of such relations at the legislative level (as a rule, the term of such agreements does not exceed 10 years). The manager receives a fee for managing the facility. Thus, the private operator assumes only part of the risks of making management decisions. And the main part of capital investments is made by the property owner, while the managing company can carry out minor repairs of the equipment (Chernyshov, 1998).

However, it should be noted that this form of partnership does not provide an opportunity to solve the problems associated with the need for significant capital investment. Therefore, financially attractive objects are usually transferred to trust management, but their efficiency does not satisfy the owner.

Another form of cooperation between the subjects of housing and communal services is the lease relationship. P. Bubenko, I. Pokutsa and V. Vashchenko consider that under the lease agreement, the private company receives the exclusive right to operate the facilities of the utility company for a fixed fee, usually for a long period, which is determined by the agreement. A private investor operates and maintains the system, repairs, reconstructs, charges and collects payments, assuming significant commercial risk, because in the absence of subsidies, profits can only be made if revenues from consumer services exceed costs and depreciation. The state institution remains the owner of the enterprise and in most cases is responsible for making capital investments. According to the current Ukrainian legislation, leasing agreements may be concluded in the public utilities of Ukraine (Bubenko, Pokutsa and Vashchenko, 2013).

In general, Ukraine has a legal framework for leasing relations. Thus, in 2019, the Law of Ukraine "On Lease of State and Communal Property" (The Verkhovna Rada of Ukraine, 2019b) was adopted; the Law of Ukraine "On Leasing” (The Verkhovna Rada of Ukraine, 2003) is in force, so the subjects of housing and communal services can cooperate in these forms of relations. In accordance with the established requirements of the law, the utility company may provide the tenant with the use for a specified period of property owned by the enterprise. Property, plant and equipment (i.e. separately identified assets) are leased only. In this case, the object of lease can be both a separate property and an integral property complex with a complete cycle of production (works, services), provided to him by the land on which it is located, autonomous utilities, energy supply system.

The profitability of the lease is obvious to private business: they get to use strategically important objects, so they will plan to get the maximum return on investment by raising prices for services. Eventually, consumers of these services will suffer and an appropriate chain will be created. It will lead to opposition and social tension on the part of the population, and appropriate action by the government, which must protect its interests.

There are not enough advantages for the state and communal enterprises from lease agreements, because the lease agreement does not provide for capital investments in new equipment or fixed assets modernization. By investing financial resources in the moderni- 
zation of fixed assets or technical reequipment of production, the tenant may receive compensation for technical innovations or "separate" them from the property of the utility after the end of the contract. Therefore, this form of cooperation is not beneficial to either the tenant or the utility company, and therefore is not perfect due to the regulatory unregulated lease relations in the utility sector, also the specifics of the industry is not taken into account.

Today, the lack of capital investment in utilities and limited budgets at all levels, leads to the fact that one of the most attractive forms of raising funds is the mechanism of transfer of utilities to the concession. The experience of many developed countries shows that one of the most effective ways to ensure the quantitative and qualitative characteristics of communal property is to attract private capital to the financing and management of these objects, but not through their privatization, but on the basis of concessions.

Concession is the process of granting the right to create and (or) manage the object of concession on the terms of property liability by the concessionaire and possible division of business risk to the authorities or local government, concluding an agreement on a paid and term basis.

The Law of Ukraine "On Concession" determines the terms of concluding agreements, procedure and mechanism of concession relations (The Verkhovna Rada of Ukraine, 2019a).

The main source of financial income of the business entity (concessionaire) is the income from the provision of services, which depends on the level of tariffs. Undoubtedly, in the conditions of long-term work of a private company in the economy there are changes that lead to a revision of the established tariffs. In addition to the management and operation of the concession object, the responsibilities of a private investor include investment in reconstruction, modernization, overhaul. The created property is also trans- ferred to the ownership of the state or urban agglomerations.

The most important of the provisions for the use of the concession form is that the choice of the concessionaire is made on an open competitive basis. This should be the mechanism that creates the conditions for the development of competition between players at the stage of entering the markets of housing and communal services.

Consider the main advantages and disadvantages of concession relations in housing and communal services (Table 1).

Summarizing the above, it is necessary to state the benefits for all participants in concession agreements. Minor disadvantages of forms of concession are low or lost profits, bankruptcy of the enterprise, but such a scenario can be obtained in the same way in normal business conditions.

As domestic experience shows, almost 96\% of public-private partnership agreements in Ukraine are not fulfilled. After all, many issues need to be addressed. These are issues related to compliance with the requirements of service quality, the mechanism of control over the targeted use of depreciation deductions by the concessionaire; the formation and establishment of tariffs for services and the conditions of their revision; formation of relations between partners on guarantees not only in receiving financial rewards, but also possible losses in case of unsuccessful project implementation; formation of public opinion on the project implementation in order to create stable favorable conditions for its implementation, guarantees of invariability of contract terms during the change of power and political situation in the country and region where the project is implemented, opportunities and conditions of private investor withdrawal in case of such circumstances etc.

This requires detailed improvement not only of the projects but also the terms of the contract, the possibility of changing it, because given the long projects duration of, it is impossible to predict all possible changes. 


\section{Table 1. Advantages and disadvantages of concession relations in housing and} communal services

\begin{tabular}{|c|c|}
\hline Advantages & Disadvantages \\
\hline \multicolumn{2}{|c|}{ Urban agglomerations } \\
\hline $\begin{array}{l}\text { - the concession allows to attract long-term pri- } \\
\text { vate investments in the unprofitable sector; } \\
\text { - objects created by the concessionaire in com- } \\
\text { pliance with the terms of the concession agreement } \\
\text { automatically become communal property, and } \\
\text { local governments retain ownership of the property } \\
\text { improved, reconstructed and technically re- } \\
\text { equipped at the expense of the concessionaire } \\
\text { (Karelina, 2010); } \\
\text { - release of budgetary resources, while payments } \\
\text { of concessionaires can be directed on solving other } \\
\text { equally important social problems. }\end{array}$ & $\begin{array}{l}\text { there is a possibility of losing control } \\
\text { over the growth of tariffs, which may be caused } \\
\text { by the efforts of the concessionaire to maximize } \\
\text { profits; } \\
\text { - weak control can affect the quality of } \\
\text { services; } \\
\text { - Concession creates opportunities for cor- } \\
\text { ruption, as long-term agreements do not contain } \\
\text { clear regulatory provisions; unattractive invest- } \\
\text { ment image of Ukraine negatively affects the } \\
\text { number of potential applicants for participation } \\
\text { in the concession tender (Vikarchuk, 2005). }\end{array}$ \\
\hline
\end{tabular}
Object of concession

- improving the technical condition of the utility facility with minimal local budget costs;

- $\quad$ the enterprise remains in communal ownership, and its activities are controlled by local governments;

- $\quad$ concessions provide a comprehensive approach to the processes of design, construction, operation and maintenance of infrastructure;

- $\quad$ the quality and range of services increase;

- $\quad$ the monopoly right of the state is abolished; creating a competitive environment in the housing market.

\section{Private investor (concessionaire)}

- concluding a concession agreement for a long term (from 10 to 50 years) allows the concessionaire to carry out strategic planning of facilities, which increases his confidence in the possibility of return on investment and the level of motivation to invest in reconstruction and modernization;

- $\quad$ risk sharing between partners. bankruptcy of the concessionaire may have negative social consequences and lead to loss of public confidence in public authorities.
- $\quad$ shortfall in planned profits in case of demand reduction for the product offered by the concessionaire;

- $\quad$ low incomes caused by the low level of payment for housing and communal services and the provision by the state of benefits for the payment of housing and communal services to certain categories of the population, which does not encourage them to economical use of resources;

- $\quad$ the possibility of losing the object of the agreement in case of disputes between local authorities and the concessionaire (Zerova, 2014).

Source: improved by the author based on (Karelin, 2010; Vikarchuk, 2005; Zerova, 2014).

Also, among the main problems to be solved in the field of public-private partnership at the legislative level, it should be noted:

- budgetary and financial - requires a clear definition in the lease or concession agreement of the method of obtaining and agreeing on payments which are obligatory in case of early termination of the lease or concession agreement; it is also necessary to cre- 
ate conditions, in particular through changes in the Budget Code, under which local councils can make payments outside the current budget year;

- tariff-forming - According to the current legislation, the establishment of tariffs for heat supply services is centralized, so it is the central executive body (now the National Energy and Utilities Regulatory Commission) that establishes tariffs for heat energy to entities that provide relevant services (Sincheskul and Dymchenko, 2018).

expedient for innovative projects. It can be through raising funds in the stock market, through IPOs, SPOs, ISOs, direct investment funds, mutual investment institutions, state and non-state pension funds.

\section{Conclusions.}

It is proved that the relationship between the state and business today is extremely strategically important for the state in shaping the goals of sustainable development. Building effective relationships in housing and communal services will be a success of effective activities and will satisfy all participants: the state, business and the population.

It is proved that in modern conditions, housing and communal services is a complex hierarchical system that combines many separate subsystems and has the characteristics of a spatial economy, i.e. regional structure and scale.

The analysis of the legal and regulatory framework shows that there are only three players in the market of housing and communal services: managers, service providers and consumers. Also, there are various opportunities to establish partnerships with most existing stakeholders, including the use of publicprivate partnerships in housing and communal services.

It is investigated that among the widespread variants of private capital raising in the communal sphere the following basic forms are identified: contract for works, contract for enterprise management, lease, concession, privatization. Thus, local public authorities have the opportunity to transfer utilities in concession or lease to private investors. However, this has not become a common practice due to the complexity of their organizational mechanism.

It is proved that the most effective form of public-private partnership for housing and communal services is a concession - the process of granting, in order to meet public needs by the authorized body of executive power or local government, concluding a contract on a paid and term basis, the concessionaire the right to create and (or) manage the concession, on the terms of property liability of the concessionaire and possible business risk sharing. The advantages and disadvantages of concession relations in housing and communal services are substantiated.

It is proved that today in Ukraine the most attention is paid to the creation of hightech and engineering clusters. In addition, the development of intersectoral alliances, $R \& D$ centers, laboratories, incubators, accelerators, venture funds and innovation teams are promising. The strategic dominants of the economy digital transformation are determined. The main priority projects for investing in transformation infrastructure in 2020-2030 are presented.

It is substantiated that the model of financing through venture capital, business angels, grants, business incubators, accelerators, crowdfunding platforms, innovation teams is expedient for innovative projects. It can be through raising funds in the stock market, through IPOs, SPOs, ISOs, direct investment funds, mutual investment institutions, state and non-state pension funds.

\section{References}

Bubenko, P. T., Pokutsa, I. V. and Vashchenko, V. A. (2013), "Transformation of the process of managing utilities through the development of public-private partnerships", Scientific Bulletin of Kherson State University, vol. 3, pp. 20-23.

Chernyshov, L. N. (1998), Cenovaja y taryfnaja polytyka $v$ zhylyshhno-komunal'nom hozjajstve [Price and tariff 
policy in housing and communal services], Book World, Moscow, Russia, 248 p.

Irtyshcheva, I. O. and Kramarenko, I. S. (2014), "Investment attractiveness of the economy: inter-regional asymmetries”, Regional economy, no. 2 (72), pp. 84-95.

Karelin, O. Yu. (2010), "Concession as one of the ways of investing housing and communal services", Naukovi pratsi Kirovohradskoho natsionalnoho tekhnichnoho universytetu. Ekonomichni nauky, vol. 17, pp. 138144.

Kucherenko, V. R. (ed.) and Dzesyk, S. S. (ed.) (2009), Strategii rozvytku komunalnogo sektoru miskogo gospodarstva [Strategies for development of the municipal sector of the municipal economy], POST MEDIA, Odesa, Ukraine, $154 \mathrm{p}$.

Masyk, M. Z. (2018), "Organizational and legal mechanism of public-private partnership in the housing and communal sphere of Ukraine”, Abstract of Ph.D. dissertation, Mechanisms of public administration, Institute of Training of the State Employment Service of Ukraine of the Ministry of Social Policy of Ukraine, Kyiv, Ukraine.

Melnykova, M. V., Tarasevych, O. V. and Nesterov, H. H. (2015), "Modeling the relationship between urban CCPs and partners (taking into account existing economic competence)", Mathematical modeling in economics, no. 2, pp. 65-73.

Panasenko, I. O. (2013), "Housing and communal services as an object of state regulation", Public administration theory and practice, vol. 3, pp. 262-273.

Sincheskul, I. L. and Dymchenko, O. V. (2018), "Relationship management peculiarities of municipal heat supply companies with stakeholders", Economy and Society, no. 17, pp. 365-372, doi: https://doi.org/10.32782/2524-0072/2018-17-54

The Verkhovna Rada of Ukraine (2003), The Law of Ukraine “On Leasing”, available at: https://zakon.rada.gov.ua/laws/show/1381-15 (Accessed 23 April 2020)

The Verkhovna Rada of Ukraine (2017), The Law of Ukraine "On housing and communal services", available at: https://zakon.rada.gov.ua/laws/show/2189-19 (Accessed 23 April 2020)

The Verkhovna Rada of Ukraine (2018), The Law of Ukraine "On the Privatization of State and Communal Property”, available at: https://zakon.rada.gov.ua/laws/show/2269-19 (Accessed 23 April 2020)

The Verkhovna Rada of Ukraine (2019a), The Law of Ukraine "Concession", available at: https://zakon.rada.gov.ua/laws/show/157-IX (Accessed 23 April 2020)

The Verkhovna Rada of Ukraine (2019b), The Law of Ukraine "On leasing of state and communal property", available at: https://zakon.rada.gov.ua/laws/show/157-IX (Accessed 23 April 2020)

Vikarchuk, O. I. (2005), "The role of concessions in shaping the investment environment", Finansovoekonomichni problemy rozvytku pidpryiemnytstva $v$ Ukraini [Financial and Economic Problems of Entrepreneurship Development in Ukraine], Materialy Vseukrainskoi naukovo-praktychnoi konferentsii [Proceedings of the All-Ukrainian scientific-practical conference], Zhytomyr, Ukraine, October 6-7, 2005, pp. 105-107.

Zierova, O. N. (2014), "The possibility of using the concession mechanism of stimulation of investment activity in the field of housing and communal services", Fundamental and Applied Researches in Practice of Leading Scientific Schools, no. 4, available at: http://fund-issled-intern.esrae.ru/pdf/2014/4/57.pdf (Accessed 23 April 2020)

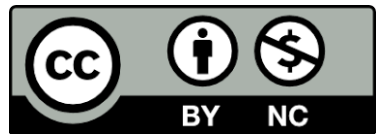

Цей твір ліцензовано на умовах Ліцензії Creative Commons «/з Зазначенням Авторства - Некомериійна 4.0 Міжнародна» (CC BY-NC 4.0). This is an open access journal and all published articles are licensed under a Creative Commons "Attribution-NonCommercial 4.0 International" (CC BY-NC 4.0). 